\begin{tabular}{|l|l|l||}
\hline \multicolumn{2}{|c|}{ PublisherInfo } \\
\hline \hline PublisherName & $:$ & BioMed Central \\
\hline \hline PublisherLocation & $:$ & London \\
\hline \hline PublisherImprintName & $:$ & BioMed Central \\
\hline \hline
\end{tabular}

\title{
Power to the pufferfish
}

\begin{tabular}{|l|c|l||}
\hline \multicolumn{2}{|c|}{ ArticleInfo } \\
\hline \hline ArticleID & $:$ & 4541 \\
\hline \hline ArticleDOI & $:$ & $10.1186 /$ gb-spotlight-20020726-01 \\
\hline \hline ArticleCitationID & $:$ & spotlight-20020726-01 \\
\hline \hline ArticleSequenceNumber & $:$ & 207 \\
\hline \hline ArticleCategory & $:$ & Research news \\
\hline ArticleFirstPage & $:$ & 1 \\
\hline \hline ArticleLastPage & $:$ & 3 \\
\hline \hline & & RegistrationDate : 2002-7-26 \\
\hline ArticleHistory & $:$ & OnlineDate \\
\hline \hline ArticleCopyright & $:$ & BioMed Central Ltd2002-7-26 \\
\hline \hline ArticleGrants & $:$ & \\
\hline \hline ArticleContext & $:$ & 130593311 \\
\hline \hline
\end{tabular}




\section{Jonathan B Weitzman}

Email: jonathanweitzman@hotmail.com

Fugu rubripes is a teleost fish that comes from the Far East. The compact nature of the Fugu genome (it has about the same number of genes as the human genome crammed into one eighth of the length) makes it an attractive candidate for comparative genomic analysis. In the July 25 ScienceXpress the international Fugu Genome Consortium, led by Sydney Brenner, reports the sequencing of the $F$. rubripes genome.

The Consortium chose a whole-genome shotgun sequencing approach that involved assembling over 3.7 million sequencing reads into large scaffolds covering more than $80 \%$ of the 365 -megabase genome. Using homology-searching programs, the authors found 31,059 predicted gene loci, similar to the number of certified human genes. Gene loci represent about one third of the genome, with clear variation in gene density. Comparative genome analysis allowed the Consortium to identify almost one thousand novel putative gene loci in the human genome.

Repetitive sequences account for $2.7 \%$ of the Fugugenome, an order of magnitude less than in mammals. But there are at least 40 different families of transposable elements, many more than in the human genome. The authors suggest that the pufferfish genome has experienced rapid deletion of nonfunctional sequences. The compactness of the genome is also reflected in the small size of introns, threequarters of which are less than 425 nucleotides long. Careful analysis revealed the existence of several "giant genes" with extended introns that are spread over very large distances, significantly greater than their human homologs. The Consortium found little evidence for large tandem duplications, but did find fish-specific segmental duplications of certain loci.

The similarities and the differences between the Fugu and human genomes are enlightening. Around a quarter of human proteins have no homology match within the Fugu genome. These include genes encoding inflammatory cytokines and immune system components. The Fugugenome has an excess of potassium channel subunits and kinases, whereas the human genome contains more zinc-finger proteins and novel receptor families.

The Consortium estimates the cost of sequencing the pufferfish genome at around $\$ 12$ million, two orders of magnitude less than for the human genome. This cost-effective project has generated a key resource for comparing vertebrate genomes, and for gaining insights into the evolution of terapods and teleosts. 


\section{References}

1. Characterization of the pufferfish $(F u g u)$ genome as a compact model vertebrate genome.

2. ScienceXpress, [http://www.sciencemag.org/sciencexpress/recent.shtml]

3. Fugu genome project, [http://www.fugubase.org]

4. Ensembl, [http://www.ensembl.org] 